\title{
МЕЖДИСЦИПЛИНАРНЫЕ ИССАЕДОВАНИЯ
}

\section{INTERDISCIPLINARY RESEARCH}

DOI: $10.12731 / 2658-6649-2021-13-3-305-320$

UDC 338.43.02

\section{IMPROVEMENT OF INFORMATION QUALITY ON STATE ASSISTANCE IN ACCOUNTING AND REPORTING OF AGRICULTURAL COMPANIES}

\author{
V.B. Malitskaya, N.N. Volkova, A.A. Aksenova, \\ I.E. Konovalenko, D.N. Osyanin
}

Agriculture is of great importance for the Russian economy and is one of its most stable and fast growing sectors. The farming experience in the European agro developed countries confirms the need for active state intervention explained by the special features of the sector. Our country allocates huge resources to support of agriculture. Russia's mechanisms of agricultural subsidies are improved on a constant basis meaning that the accounting and financial reporting systems as information tools of management should be adapted to the functional changes in modern agricultural companies, including improvement of subsidy mechanisms. Our research assesses accounting for state aid and formation of accounting reporting indicators taking agricultural firms of the Voronezh region as an example. It also develops the directions of further activities. The results will help improve the information basis for managerial decisions when distributing and analyzing effectiveness of state aid in the agrarian firms.

Keywords: agrarian formations; accounting; reporting; state aid; state programme; subsidy mechanisms; agriculture; subsidies

For citation. Malitskaya V.B., Volkova N.N., Aksenova A.A., Konovalenko I.E., Osyanin D.N. Improvement of Information Quality on State Assistance in Accounting and Reporting of Agricultural Companies. Siberian Journal of Life Sciences and Agriculture, 2021, vol. 13, no. 3, pp. 305-320. DOI: 10.12731/2658-6649-2021-13-3-305-320 


\title{
СОВЕРШЕНСТВОВАНИЕ ФОРМИРОВАНИЯ ИНФОРМАЦИИ О ГОСУДАРСТВЕННОЙ ПОМОЩИ В БУХГАЛТЕРСКОМ УЧЕТЕ И ОТЧЕТНОСТИ СУБЪЕКТОВ АГРАРНОЙ СФЕРЫ
}

\author{
В.Б. Малицкая, Н.Н. Волкова, А.А. Аксенова, \\ И.Е. Коноваленко, Д.Н. Осянин
}

Сельское хозяйство играет огромную роль в экономике России и является одной из наиболее стабильно и быстрорастущих ее отраслей. Опыт ведения сельского хозяйства в аграрно развитых европейских странах подтверждает, что спеиифика данной отрасли обусловливает активное вмешательство государства в проиесс ее функиионирования. На поддержку сельского хозяйства нашей страны выделяются огромные ресурсы. Постоянно совершенствуются механизмы субсидирования отрасли сельского хозяйства в России. В этой связи система бухгалтерского учета и бухгалтерской отчетности, выступая в качестве информачионного источника обеспечения управления, должна адаптироваться $\kappa$ происходящим изменениям во внешней среде функционирования современных сельскохозяйственных организачий, обусловленным, в том числе, совершенствованием механизма государственного субсидирования. В проведенном исследовании дана оченка бухгалтерского учета государственной помощи и формирования показателей бухгалтерской отчетности на примере сельскохозяйственных организаиий Воронежской области и разработаны направления дальнейшего развития. Полученные результаты позволят усовершенствовать порядок формирования информачионной базы для принятия управленческих решений при распределении и анализе эффективности государственной помощи в аграрных формированиях.

Ключевые слова: аграрные формирования; бухгалтерский учет; бухгалтерская отчетность; государственная помощь; государственная программа; механизмы субсидирования; сельское хозяйство; субсидии

Для цитирования. Малицкая В.Б., Волкова Н.Н., Аксенова А.А., Коноваленко И.Е., Осянин Д.Н. Совершенствование формирования информации о государственной помощи в бухгалтерском учете и отчетности субъектов аграрной сферы // Siberian Journal of Life Sciences and Agriculture. 2021. T. 13, № 3. C. 305-320. DOI: 10.12731/2658-6649-2021-13-3-305-320

\section{Introduction}

State help to companies becomes an integral part of a market economy. Agriculture is a strategically important, priority instrument in ensuring food security 
of a state and the need of state aid here is obvious. Long-term experience has demonstrated that it is the government that can regulate financial injections into agriculture taking into account possible development trends in the sector. The Voronezh region was second in 2019 by the volume of subsidies to the farmers in the Central Federal District (7,618.9 mln rbl). It implements regional state programme Development of Agriculture, Food Production and Infrastructure of the Agro-Food Market. The federal government allocated $256.2 \mathrm{bln}$ rbl to the state agriculture programme in 2021, which is much lower than in 2020 ( $308.8 \mathrm{bln} \mathrm{rbl).} \mathrm{At} \mathrm{the} \mathrm{same} \mathrm{time,} \mathrm{the} \mathrm{federal} \mathrm{government} \mathrm{plans} \mathrm{a} 279.7 \mathrm{bln}$ rbl financing of the programme for 2022 and $295.5 \mathrm{bln}$ rbl for 2023. The key source of information for the external users on the amount of state help received by the agricultural organizations is accounting (financial) reporting compiled from accounting records. Unfortunately, we have to state that the modern accounting and reporting systems do not fully meet the agriculture management goals (Beisland, 2013; Patten, 2015; Boyko et al., 2019). Reflecting state help in accounting and reporting in compliance with the Russian and international legislation; details of information about the types of state assistance in the accounting system (Milne, 2002); creation of industry-specific accounts in accordance with the state help mechanism; effectiveness of the use of support (Muller, 2015); a higher return on invested state funds are pressing issues and require further improvement.

\section{Literature review}

State aid is an integral part of government regulation and is a combination of different tools and instruments, preferential and free financing of the most economically disadvantaged industries. The state help notion has good interpretation both in the local and international practices. For instance, in Russian Accounting Standard 13/2000 "State Aid Accounting" the state assistance notion is defined as "an increase in economic benefits of an organization as a result of receipt of assets (cash, other property)". Amendments to the statutory acts say that Russian Accounting Standard 13/2000 is about the subsidies provided from the budgets of the Russian Federation budget system and the budgets of the state extra-budgetary funds; at that, state support in the form of subventions is excluded. Internationally, the statutory document, which defines the state aid notion is International Accounting Standard (IAS) 20 "Accounting for Government Grants and Disclosure of Government Assistance" (Ahmed, 2013). We believe that IAS 20 provides a more accurate definition of state aid: "government actions aimed at providing economic benefits to a company or a group of 
companies meeting necessary criteria". For agriculture, IAS 41 "Agriculture" is applied internationally (Lehoux, 2019; Strizhenok and Ivanov, 2021).

IAS 41 differs from IAS 20 in prescribing the order of accounting in cases when a state grant is applied to a biological asset valued at fair value less the cost of sales, or when a state grant prohibits company involvement in a certain type agricultural business. We believe that IAS can boast more detailed theoretical aspects, while RAS is better from a practical point of view (the order of accounting). According to Adams (2008), Peter (2016) the terms "subsidies" and "compensations" can conceal different economic instruments -- revenue from the sale of goods, works, services accounted for under Russian Accounting Standard 9/99, as well as support covered by Russian Accounting Standard 13/2000 "Accounting for Government Assistance". When a company cannot differentiate between these two types of budget funds and accounts for them all as revenue (income), it runs the risk of getting claims from the tax authorities for underestimating the tax base for VAT and the income tax, usually supported by courts (Caims, 2004; Akhmadeev, 2019; Rahman, 2018).

In the modern literature a number of problems are discussed with regard to the topic of the research. This concerns the volume of funding allocated to support the agro-industrial complex in 2021 in Russia in general and the Voronezh region in particular; reflection in accounting and financial statements of the received subsidies (Fomina, 2020; Kokorev, 2019); the impact of the coronavirus pandemic on the accounting of government subsidies (Sharonova, E.A., 2020); methodological aspects of assessing the effectiveness of government subsidies (Pechenkin, V.G., 2010; Dudukalov et al., 2020), etc.

\section{Matter of research}

Farmers receive active government assistance. The chief Voronezh region distributor of regional budget funds and the funds provided to the region from the central government for grants is the agrarian policy department of the Voronezh region. The breakdown of state assistance received by the Voronezh region's farmers in 2018-2019 is presented in Table 1. We can see that the key directions of subsidies in the period were subsidies to attain the targets of the regional agriculture programmes (a so-called single subsidy), grants for floating support of plant growing, subsidies to raise productiveness of dairy cattle breeding and subsidies to compensate part of interest on investment credits to the farmers.

State assistance to the farmers involves passage of a number of consecutive stages, including an application with the attachment of documents confirming the right for a grant to the regional agriculture department (Susiarjo, 2006; Ma- 
larev et al., 2020). We should note that the government of the Voronezh region develops and approves an order of getting a subsidy. The list of documents for application for a grant is part of the order. The forms of application are also approved. The rates of the subsidies are approved by the agriculture department of the Voronezh region. This means that a farmer only has to comply strictly with the regulations of the order and fill in the documents correctly (Table 2).

The breakdown of state assistance received by the farmers of the Voronezh region in 2018-2019

\begin{tabular}{|c|c|c|c|c|c|c|c|c|}
\hline \multirow{3}{*}{ Indicator } & \multicolumn{4}{|c|}{$\begin{array}{c}\text { OJSC Rassvet of the Verkh- } \\
\text { nemamonsky district }\end{array}$} & \multicolumn{4}{|c|}{$\begin{array}{l}\text { OJSC Agrofirma Tikhy Don } \\
\text { of the Pavlovsk district }\end{array}$} \\
\hline & \multicolumn{2}{|c|}{2018} & \multicolumn{2}{|c|}{2019} & \multicolumn{2}{|c|}{2018} & \multicolumn{2}{|c|}{2019} \\
\hline & $\begin{array}{l}\text { thou- } \\
\text { sand } \\
\text { rbl. }\end{array}$ & $\%$ & $\begin{array}{l}\text { thou- } \\
\text { sand } \\
\text { rbl. }\end{array}$ & $\%$ & $\begin{array}{l}\text { thou- } \\
\text { sand } \\
\text { rbl. }\end{array}$ & $\%$ & $\begin{array}{l}\text { thou- } \\
\text { sand } \\
\text { rbl. }\end{array}$ & $\%$ \\
\hline $\begin{array}{l}\text { Budget funds, total, } \\
\text { including }\end{array}$ & 6423 & 100.0 & 10249 & 100.0 & 295 & 100.0 & 4137 & 100,0 \\
\hline $\begin{array}{l}\text { Grants to attain the } \\
\text { targets of the region- } \\
\text { al agriculture pro- } \\
\text { grammes }\end{array}$ & 4114 & 64.05 & 4425 & 43.17 & - & - & 801 & 19.36 \\
\hline $\begin{array}{l}\text { Grants for floating aid } \\
\text { for plant breeding }\end{array}$ & 632 & 9.84 & 4868 & 47.49 & 295 & 100.0 & - & - \\
\hline $\begin{array}{l}\text { Grants to increase pro- } \\
\text { duction in dairy cattle } \\
\text { breeding }\end{array}$ & 923 & 14.37 & 956 & 9.34 & - & - & 2976 & 71.94 \\
\hline $\begin{array}{l}\text { Grants to compensate } \\
\text { part of interest on in- } \\
\text { vestment credits to the } \\
\text { farmers }\end{array}$ & 754 & 11.74 & - & - & & & & \\
\hline Other subsidies & - & - & - & - & - & - & 360 & 8.70 \\
\hline
\end{tabular}

Our analysis of the current accounting for the receipt and use of state assistance in some agricultural companies revealed the absence of the optimally structured system of information flows on targeted financing on account 86 "Targeted Financing", which prevents its best analysis. Besides, we established that some of the economic subjects under analysis never use account 86 "Targeted Financing" and reflect state aid only on accounts 76 "Settlements with Different Debtors and Creditors" and 91 "Other Income and Expenditure" conflicting with the 2020 amendments to Russian Accounting Standard 13/2000 "Accounting for State Assistance". 
Table 2.

Documenting the receipt of subsidies by agricultural producers in the Voronezh region

\begin{tabular}{|c|c|c|}
\hline Subsidy & $\begin{array}{l}\text { Regulatory doc- } \\
\text { ument }\end{array}$ & The list of documents for application \\
\hline 1 & 2 & 3 \\
\hline $\begin{array}{l}\text { Grants to attain } \\
\text { the targets of the } \\
\text { regional agricul- } \\
\text { ture programmes } \\
\text { (to support elite } \\
\text { seed production) }\end{array}$ & $\begin{array}{l}\text { Regulation of the } \\
\text { Voronezh region } \\
\text { government dated } \\
\text { February } 07,2018 \\
\text { № } 110 \text { (ed. dated } \\
\text { August } 26,2020 \text { ) } \\
\end{array}$ & $\begin{array}{l}\text { application; statement of the tax authority } \\
\text { on settlement of taxes, penalties and fines; a } \\
\text { copy of documents confirming the purchase } \\
\text { and sowing of spring and winter crops; the } \\
\text { certificates of seed conformity; information } \\
\text { about the results of sowing; a financial report }\end{array}$ \\
\hline $\begin{array}{l}\text { Grants for float- } \\
\text { ing aid for plant } \\
\text { breeding }\end{array}$ & $\begin{array}{l}\text { Regulation of the } \\
\text { Voronezh region } \\
\text { government dated } \\
\text { March } 18,2016 \\
\text { № } 164 \text { (ed. dated } \\
\text { June } 30,2016 \text { ) } \\
\end{array}$ & $\begin{array}{l}\text { application; statement of the tax authority on } \\
\text { settlement of taxes, penalties and fines; infor- } \\
\text { mation about harvesting; financial report; list } \\
\text { of submitted documents }\end{array}$ \\
\hline $\begin{array}{l}\text { Grants to in- } \\
\text { crease produc- } \\
\text { tion in dairy } \\
\text { cattle breeding }\end{array}$ & $\begin{array}{l}\text { Regulation of the } \\
\text { Voronezh region } \\
\text { government dated } \\
\text { December } 28, \\
2019 \text { № } 1312\end{array}$ & $\begin{array}{l}\text { application; calculation of subsidy; informa- } \\
\text { tion about cows or/and goats of the recipient } \\
\text { of the grant; information about milk output, } \\
\text { milk sold and/or sent to the applicant's own } \\
\text { processing; documents confirming the sales } \\
\text { of milk and/or its sending to the applicant's } \\
\text { own processing facilities; information about } \\
\text { dairy productivity of cows; financial report; } \\
\text { force majeure documents }\end{array}$ \\
\hline $\begin{array}{l}\text { Grants to com- } \\
\text { pensate part of } \\
\text { interest on in- } \\
\text { vestment credits } \\
\text { to the farmers }\end{array}$ & $\begin{array}{l}\text { Regulation of the } \\
\text { Voronezh region } \\
\text { government dated } \\
\text { October 19, } 2018 \\
\text { №910(ed. dated } \\
\text { September 03, } \\
\text { 2020) (ed. dated } \\
\text { September 03, } \\
\text { 2020) }\end{array}$ & $\begin{array}{l}\text { a) after opening a credit account to receive a } \\
\text { loan under a credit line: copies of the credit } \\
\text { agreement certified by the credit institution; } \\
\text { copies of the payment order and an extract } \\
\text { from the borrower's loan account on obtain- } \\
\text { ing the loan; a repayment schedule and an } \\
\text { interest payment schedule; a document indi- } \\
\text { cating the number of the borrower's account } \\
\text { opened in a credit institution to receive funds } \\
\text { from the budget of a Russian Federation } \\
\text { subject; } \\
\text { 6) after payment of interest: subsidy appli- } \\
\text { cation; calculation of the volume of subsidy; } \\
\text { copies of payment orders to pay interest cer- } \\
\text { tified by a credit organization; copies of doc- } \\
\text { uments confirming targeted use of the loan; } \\
\text { financial report }\end{array}$ \\
\hline
\end{tabular}


The farmers present a balance sheet, a financial report and explanation to it, a cash flow statement present information about imputed and actually received subsidies in industry reporting form № 10-APK "Report on Targeted Financing". The form consists of 7 parts for individual reflection of information on state assistance on some branches of plant and cattle breeding as well as on agricultural insurance (in the form of a compensating subsidy in plant breeding); short-term crediting in agriculture; support to small enterprises (grants); agricultural investment activities; federal targeted programmes; other state programmes and other subsidies (Bykanova, 2018; Zvereva, 2020; Zakharov et al., 2020).

The current presentation of information on state subsidies in federal law No. 10-APK for some sections is detailed as follows: for elite seed breeding, traditional plant breeding, payments of insurance premiums and floating support (in plant breeding section 10.2); for support of pedigree cattle breeding, traditional cattle breeding, payments of insurance premiums and support of milk production (in cattle breeding section 10.3), etc. It is also worth noting that judging by the name, sections 10.2 and 10.3 are devoted to compensating subsidies, which contain information on stimulating subsidies as a separate column.

\section{Discussion and results}

Modern economic literature (Kozmenkova, 2014; Nuriyeva, 2016; Zhukovskyy et al., 2019) has been raising the question of creation of a multi-level system of accounting for state aid as part of targeted financing for several years. Although the system can be perceived as complicated and labour-consuming, we think that it is extremely necessary because it provides well for the users informationally (Leuz,2003; Loureiro, 2015). Besides, we should note that introduction of analytical accounting for state aid should be done by target.

We think that the need for further improvement of information on state assistance in accounting and reporting of farmers is conditioned by the following:

1. There is a need to create a flexible system of accounting for targeted financing, including several levels (subaccounts on orders 1, 2, etc, as well as analytical accounts), which would be formed in accordance with the established mechanism of assistance to agriculture.

2. Development of the best solutions for an enterprise's structure of information flows about targeted financing on account 86 "Targeted Financing" 
should help create the best analysis possibilities of information on state assistance.

3. We need to adjust the name and contents of the industry reporting indicators № 10-APK “Report on the Funds of Targeted Financing”, which, in its turn, connected to consolidation of all subsidies into one, floating support and support to increase productivity in dairy cattle breeding in the form of single subsidy (Morozova, 2019; Movchan and Yakovleva).

Our research helped us formulate the following proposals for further development of information on state aid in accounting and reporting of agricultural companies:

1. We suggest our own structure of account 86 "Targeted Financing" for accounting for state subsidies to the farmers (Table 3). The basis for our proposal is the Voronezh region subsidy mechanism, which was changed in 2020 (Chart 1), the contents of the sectorial (agriculture) form of reporting on the funds of targeted financing and some orders approved by the government of the Voronezh region to regulate provision of grants, which we discussed in Table 2. Thus we suggest opening ledger subaccounts for the enlarged groups of subsidies in account 86 "Targeted Financing" - 86-1 "Combined Subsidies for the Development of Agriculture", 86-2 "Subsidies for Investment Credits", 86-3 "Subsidies to Compensate Part of Costs to Create and Upgrade Agricultural Facilities", 86-4 "Subsidies under Federal Target Programmes", 86-5 "Other Subsidies", etc. Subledger accounts should be opened by the type (subgroup) of subsidies. In particular, this is applicable for the so-called united subsidy to develop agricultural sectors. We suggest calling subledger account 86-1-1 "Compensating Subsidies", while subledger account 86-1-2 - "Stimulating Subsidies".

2. We have formulated a list of analytical accounts for the proposed ledger and subledger accounts in account 86 "Targeted Financing" by the type of grants to ensure the best information structure for account 86 "Targeted Financing" and increase analytical possibilities of information about state assistance in the accounting system (table 3 ) using agricultural companies of the Voronezh region - OJSC Rassvet of the Verkhnemamonsky district and OJSC Agrofirma Tikhy Don of the Pavlovsk district. For instance, subledger account 86-1-1 Compensating Subsidies should have the following analytical account: Subsidies to Stimulate Growth of Grains, Legumes and Oilseeds, Subsidies for Elite Seed Production, Subsidies to Develop Meat Animal Husbandry (cattle of meat breed), Subsidies to Compensate Part of Costs to Support Milk Production, etc. We suggest opening the following analytical positions in subledg- 
er account 86-1-2 Stimulating: Subsidy to Stimulate Production of Oilseeds, Subsidy to Stimulate Development of Specialized Meat Husbandry as Part of a Priority Agriculture Subsector, Subsidy to Compensate Part of Costs to Support Milk Production, etc. As accounting is getting automated, analytical accounting is arranged by choosing the necessary subaccount for a subsidy as suggested in table 3 .

3. We put forward the proposals to improve industry reporting № 10-APK Report on the Funds of Targeted Financing presented in Table 4.

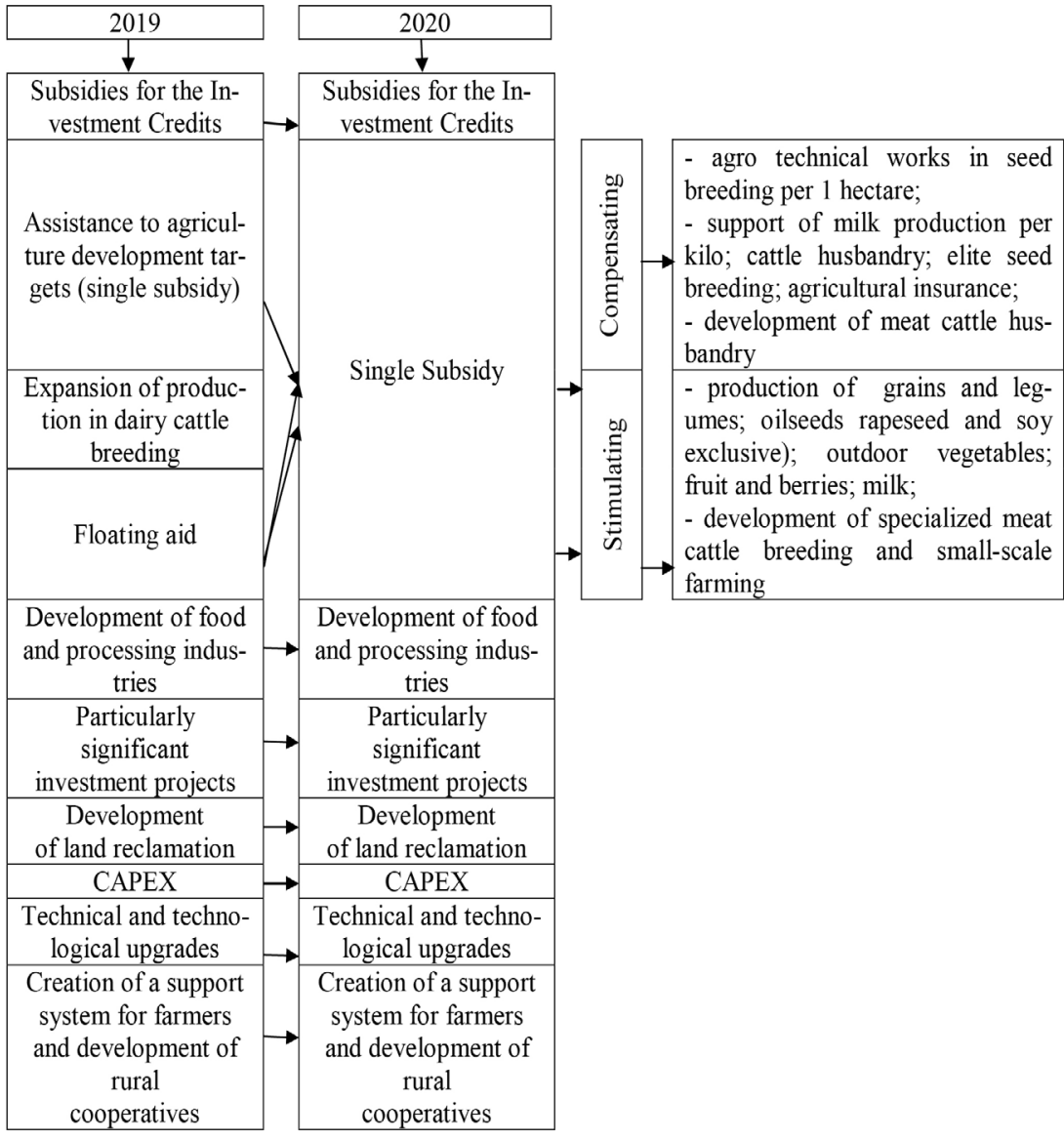

Chart 1. The agriculture subsidy mechanism of the Voronezh region in 2019-2020 was taken as the basis to structure information for account 86 "Targeted Financing" 
Table 3.

Proposed structure of account 86 "Targeted Financing" to account for state subsidies

\begin{tabular}{|c|c|c|c|}
\hline $\begin{array}{c}\text { AC- } \\
\text { COUNT }\end{array}$ & $\begin{array}{l}\text { LEDGER } \\
\text { ACCOUNT }\end{array}$ & $\begin{array}{l}\text { SUBLEDGER } \\
\text { ACCOUNT }\end{array}$ & $\begin{array}{c}\text { ANALYTICAL ACCOUNTS } \\
\text { (ABSTRACT BY TYPE OF SUBSIDY) }\end{array}$ \\
\hline \multirow[t]{5}{*}{$\begin{array}{l}86 \text { Target- } \\
\text { ed financ- } \\
\text { ing }\end{array}$} & \multirow[t]{2}{*}{$\begin{array}{l}86-1 \text { United } \\
\text { subsidies } \\
\text { to develop } \\
\text { agricultural } \\
\text { Sectors }\end{array}$} & $\begin{array}{l}86-1-1 \text { Com- } \\
\text { pensating sub- } \\
\text { sidies }\end{array}$ & $\begin{array}{l}\text { 1. Subsidies to boost production of } \\
\text { grains, legumes and oilseeds. } \\
\text { 2. Subsidies to support elite seed breed- } \\
\text { ing. } \\
\text { 3. Subsidies to develop meat animal } \\
\text { husbandry (cattle of specialized meat } \\
\text { breeds). } \\
\text { 4. Subsidies to compensate part of costs } \\
\text { to support milk production. } \\
\text { 5. Subsidies aimed at boosting dairy } \\
\text { cattle productivity (per } 1 \text { liter of sold } \\
\text { milk) } \\
\text { 6. Etc. }\end{array}$ \\
\hline & & $\begin{array}{l}\text { 86-1-2 Stim- } \\
\text { ulating Sub- } \\
\text { sidies }\end{array}$ & $\begin{array}{l}\text { 1. Subsidy to stimulate oilseed production. } \\
\text { 2. Subsidy to stimulate specialized meat } \\
\text { cattle breeding within the priority sub- } \\
\text { sector of the rural economy. } \\
\text { 3. Subsidy to compensate part of the } \\
\text { costs to boost milk production. } \\
\text { 4. Etc. }\end{array}$ \\
\hline & $\begin{array}{l}86-2 \text { Sub- } \\
\text { sidies for } \\
\text { investment } \\
\text { credits }\end{array}$ & & $\begin{array}{l}\text { 1. Subsidy to compensate part of the } \\
\text { costs to pay interest on investment } \\
\text { credits. }\end{array}$ \\
\hline & $\begin{array}{l}86-3 \text { Sub- } \\
\text { sidies to } \\
\text { compensate } \\
\text { part of costs } \\
\text { to create } \\
\text { and upgrade } \\
\text { agricultural } \\
\text { facilities }\end{array}$ & & $\begin{array}{l}\text { 1. Subsidy to buy tractors, agricultural } \\
\text { machines and equipment produced in } \\
\text { the Voronezh region. } \\
\text { 2. Subsidy to compensate part of direct } \\
\text { costs of creation and/or modernization } \\
\text { of storages. } \\
\text { 3. Etc. }\end{array}$ \\
\hline & $\begin{array}{l}86-4 \text { Subsi- } \\
\text { dies under } \\
\text { the Federal } \\
\text { Target Pro- } \\
\text { gramme }\end{array}$ & & $\begin{array}{l}\text { 1. Development of Russian rural land rec- } \\
\text { lamation in 2014-2020. } \\
\text { 2. Sustainable development of rural terri- } \\
\text { tories in 2014-2017 and until } 2020 \text {. }\end{array}$ \\
\hline $\begin{array}{l}86 \text { Tar- } \\
\text { geted fi- } \\
\text { nancing }\end{array}$ & $\begin{array}{l}86-5 \text { Other } \\
\text { Subsidies }\end{array}$ & & $\begin{array}{l}\text { 1. Subsidy to create and develop agricul- } \\
\text { tural consumer cooperatives. } \\
\text { 2. Etc. }\end{array}$ \\
\hline
\end{tabular}


Table 4.

Proposals to improve industry reporting № 10-APK Report on the Funds of Targeted Financing presented in Table 4

\begin{tabular}{|l|l|}
\hline \multicolumn{1}{|c|}{ Existing report } & \multicolumn{1}{|c|}{ Proposed report } \\
\hline $\begin{array}{l}\text { Section (code, name) } \\
\text { received state aid }\end{array}$ & \multicolumn{1}{c|}{ Section (code, name) } \\
\hline $\begin{array}{l}\text { 10-2. State support of some seed and animal breed- } \\
\text { ing subsectors as well as agricultural insurance (in } \\
\text { the form of compensating seed breeding subsidy) }\end{array}$ & $\begin{array}{l}\text { 10-1. Summarized information } \\
\text { state aid }\end{array}$ \\
\hline $\begin{array}{l}\text { 10-3. State support of some seed and animal breed- } \\
\text { ing subsectors as well as agricultural insurance (in } \\
\text { agriculture } \\
\text { the form of compensating animal breeding subsidy) }\end{array}$ & $\begin{array}{l}\text { 10-3. State support to compen- } \\
\text { sate part of interest on invest- } \\
\text { ment agricultural credits }\end{array}$ \\
\hline 10-4. State support of short-term crediting & $\begin{array}{l}\text { 10-4. State support to com- } \\
\text { pensate part of direct costs to } \\
\text { create and upgrade agricultural } \\
\text { facilities }\end{array}$ \\
\hline 10-5. State support of small firms (grants) & $\begin{array}{l}10-5 . \text { State support as part of } \\
\text { the Federal Target Programme }\end{array}$ \\
\hline 10-6. State support of investment in agriculture & 10-6ther state support \\
\hline $\begin{array}{l}\text { 10-7. State support as part of federal projects and } \\
\text { state agency programmes, other directions of state } \\
\text { support of agriculture }\end{array}$ & \\
\hline
\end{tabular}

We think we should provide for the following groups of subsidies in form № 10-APK:

- 10-1 "Summarized information on state assistance to the farmers";

- 10-2 "State assistance as part of unified subsidies to develop agriculture";

- 10-3 "State assistance to compensate part of interest on investment credits in agriculture";

- 10-4 "State assistance to compensate part of direct costs to create and modernize agriculture facilities";

- 10-5 "State assistance as part of the Federal Target Programme";

- 10-6 "Other state assistance".

This is a way to reduce the number of subsidies from 7 to 5 .

We believe that our proposals will help increase the quality of information on state assistance in accounting and reporting of farmers.

This study was financed by a grant from the Plekhanov Russian University of Economics 


\section{References / Сиисок литературь}

1. Adams C. A commentary on: Corporate social responsibility reporting and reputation risk management. Accounting, Auditing \& Accountability Journal, 2008, vol. 21, no. 3, pp. 365-370. https://doi.org/10.1108/09513570810863950

2. Ahmed K., Chalmers K., Khlif H. A meta-analysis of IFRS adoption effects. The International Journal of Accounting, 2013, vol. 48, no. 2, pp. 173-217. https:// doi.org/10.1016/j.intacc.2013.04.002

3. Akhmadeev R., Morozova T., Voronkova O., Sitnov A. Targets determination model for vat risks mitigation at B2B marketplaces. Entrepreneurship and Sustainability Issues, 2019, vol. 7, no. 2, pp. 1197-1216. https://doi.org/10.9770/jesi.2019.7.2(28)

4. Beisland L.A., Frestad D. How fair-value accounting can influence firm hedging. Review of Derivatives Research, 2013, vol. 16, pp. 193-217. https://doi. org/10.1007/s11147-012-9084-y

5. Boyko N.A., Chvileva T.A., Romasheva N.V. The impact of coal companies on the socio-economic development of coal mining regions and its assessment. Ugol, 2019, vol. 11, pp. 48-53. https://doi.org/10.18796/0041-5790-2019-11-48-53

6. Bykanova O.A., Akhmadeev R.G., Glubokova N.Y., Kravchuk I.S. The global market of roundwood: Financial aspects. Bulgarian Journal of Agricultural Science, 2018, vol. 24, no. 1, pp. 8-16. https://www.agrojournal.org/24/01-02.pdf

7. Caims D. The implications of IAS/IFRS for UK companies. International Journal of Disclosure and Governance1, 2004, vol. 1, pp. 107-118. https://doi. org/10.1057/palgrave.jdg.2040017

8. Dudukalov E.V., Spabekov G.O., Kashirskaya L.V., Sevbitov A.V., Voronkova O.Y., Vasyutkina L.V. Fiscal goals of regulating the activities of the institute of controlled foreign companies in the digital economy. Entrepreneurship and Sustainability Issues, 2020, vol. 8, no. 2, pp. 972-983. https://doi.org/10.9770/ jesi.2020.8.2(59)

9. Fomina L. Special budgetary assistance. Conditions, tax implications and accounting for small business subsidies. Financial newspaper, 2020, vol. 21, pp. 16-23.

10. Kokorev N.A. Accounting for targeted financing of agricultural organizations in the form of state aid. Agricultural accounting, 2019, vol. 9, pp. 27-39.

11. Kozmenkova S.V. Formation of Information on State Aid in Accounting and Reporting under Russian and International Standards. International Accounting, 2014, vol. 27, pp. 12-23.

12. Lehoux L., Duck H., Akhmadeev R., Morozova T., Bykanova O. Sustainable development facets: Taxation solutions for the energy industry. Journal of Security and Sustainability Issues, 2019, vol. 9, no. 2, pp. 457-472. https://doi. org/10.9770/jssi.2019.9.2(8) 
13. Leuz C. IAS versus U.S. GAAP: Information asymmetry-based evidence from Germany's New Market. Journal of Accounting Research, 2003, vol. 41, no. 3, pp. 445-472. http://dx.doi.org/10.2139/ssrn.275348

14. Loureiro G., Taboada A.G. Do improvements in the information environment enhance insiders' ability to learn from outsiders? Journal of Accounting Research, 2015, vol. 53, no. 4, pp. 863-905. https://dx.doi.org/10.2139/ssrn.2587836

15. Malarev V., Bogdanov I., Senchilo N. Algorithm for automatic compensation of voltage dips in power supply of industrial facilities. Journal of Applied Engineering Science, 2020, vol. 18, no. 2, pp. 173-180. https://doi.org/10.5937/jaes18-26361

16. Milne M., Patten D. Securing organizational legitimacy: An experimental decision case examining the impact of environmental disclosures. Accounting, Auditing \& Accountability Journal, 2002, vol. 15, no. 3, pp. 372-405. http:// dx.doi.org/10.1108/09513570210435889

17. Morozova T.V., Akhmadeev R.G., Bykanova O.A., Philippova N.V. Harmonizing the valuation standards of the EEU agricultiral companies. International Journal of Recent Technology and Engineering, 2019, vol. 8, no. 1, pp. 21672177. https://www.ijrte.org/wp-content/uploads/papers/v8i1/A1942058119.pdf

18. Movchan I.B., Yakovleva A.A. Refined assessment of seismic microzonation with a priori data optimisation. Journal of Mining Institute, 2019, vol. 236, pp. 133-141. https://doi.org/10.31897/PMI.2019.2.133

19. Müller M.A., Riedl E.J., Sellhorn T. Recognition versus disclosure of fair values. The Accounting Review, 2015, vol. 90, no. 6, pp. 2411-2447. https://www. jstor.org/stable/26550617

20. Nuriyeva R.I. Development of Accounting and Control of the Targeted Use of Budget Funds in Agricultural Organizations: abstract of dissertation. The Cuban State Agrarian University. 2016, p. 24.

21. On Approval of State Programme of the Voronezh Region Development of Agriculture, Food Production and Agriculture Market Infrastructure - regulation of the Voronezh region government dated December 13, 2013 № 1088 (ed. dated April 28, 2018). http://pravo.gov.ru/proxy/ips/?docbody=\&nd=102169429

22. On Approval of the Order of Providing Assistance from the Regional Budget to Agricultural Producers (Excluding the People with Small Personal Land Plots), to the Organizations of the Agro-Industrial Complex Regardless of Their Organizational and Legal Forms and Peasant (Farmer) Farms, Agricultural Consumer Cooperatives for Reimbursement of Part of the Costs of Paying Interest on Investment Loans (Credits) Regulation of the Voronezh region government dated October 19, 2018 № 910 (ed. September 03, 2020). https://docs.cntd.ru/ document $/ 550223931$ 
23. On Approval of the Order of Provision of Regional Budget Subsidies to Agricultural Producers (Excluding the People with a Small Farm) for Floating Support to Seed Breeding and Development of Production of Seed Potato and Outdoor Vegetables for 2016: Regulation of the Voronezh region government dated March 18, 2016 № 164 (ed. dated June 30, 2016). https://docs.cntd.ru/document/432979504

24. On Approval of the Order of Provision of Regional Budget Subsidies to Agricultural Producers, Excluding the People with a Small Farm and Agricultural Credit Consumer Cooperatives, to Compensate Part of Costs to Support Milk Production: Regulation of the Voronezh region government dated 28.12.2019 № 1312. https://docs.cntd.ru/document/561699251

25. On Approval of the Order of Provision of Subsidies to the Agricultural Producers (Excluding the People with a Small Farm and Agricultural Credit Consumer Cooperatives) to Support Elite Seed Breeding and to Compensate Part of Seed Production Costs: Regulation of the Voronezh region government dated February 07, 2018 № 110 (ed. dated August 26, 2020). https://docs.cntd.ru/document/446652302

26. On State Programme of Agriculture Development and Regulation of the Market of Agricultural Products, Raw Materials and Food for 2013-2020. The Russian government regulation dated July 14, 2012 № 717 (ed. dated September 06, 2018). http://www.consultant.ru/document/cons_doc_LAW_133795/

27. Order of the Finance Ministry of the Russian Federation dated October 16, 2000 № 92n On Approval of Regulations on Accounting. Accounting of State Aid in Russian Accounting Standard 13/200. Accounting Standards. p. 240. http:// www.consultant.ru/document/cons_doc_LAW_29296/

28. Patten D. An insider's reflection on quantitative research in the social and environmental disclosure domain. Critical Perspectives on Accounting, 2015, vol. 32, pp. 45-50. https://doi.org/10.1016/j.cpa.2015.04.006

29. Pechenkin V.G. Methodological aspects of assessing the effectiveness of government subsidies. Bulletin of the Irkutsk State Economic Academy, 2010, vol. 2, pp. 21-23.

30. Peter C., Fiore A., Hagemann U. Improving the accounting of field emissions in the carbon footprint of agricultural products: a comparison of default IPCC methods with readily available medium-effort modeling approaches. The International Journal of Life Cycle Assessment, 2016, vol. 21, pp. 791-805. https:// doi.org/10.1007/s11367-016-1056-2

31. Rahman P.A. Analysis of stationary availability factor of two-level backbone computer networks with arbitrary topology. Journal of Physics: Conference Series, 2018, vol. 1015, no. 2. https://doi.org/10.1088/1742-6596/1015/2/022016

32. Sharonova E.A. Accounting for "coronavirus" subsidies. General ledger, 2020, vol. 12, pp. 6-21. 
33. Strizhenok A.V., Ivanov A.V. Monitoring of air pollution in the area affected by the storage of primary oil refining waste. Journal of Ecological Engineering, 2021, vol. 22, no. 1, pp. 60-67. https://doi.org/10.12911/22998993/128873

34. Susiarjo G., Sreenath S.N., Vali A.M. Optimum Supportable Global Population: Water Accounting and Dietary Considerations. Environment, Development and Sustainability, 2006, vol. 8, no. 3, pp. 313-349. https://doi.org/10.1007/s10668-005-6979-x

35. Zakharov K.V., Terehova A.A., Kozlov V.N., Bobkova E.Y., Grigoryants I.A. Problems of nature protection in Moscow. Paper presented at the IOP Conference Series: Earth and Environmental Science, 2020, vol. 548, no. 5. https:// doi.org/10.1088/1755-1315/548/5/052031

36. Zvereva A., Akhmadeev R., Morozova T., Bykanova O., Avvakumova I. Improving access to environmental information for the subjects of tax relations. 20th International Multidisciplinary Scientific Geoconference SGEM 2020, 2020, pp. 279-284. https://doi.org/10.5593/sgem2020/5.2/s21.034

37. Zhukovskyy V., Zhukovska N., Vlasyuk A., Safonyk A. Method of forensic analysis for compromising carrier-lock algorithm on 3G modem firmware. 2019 IEEE 2nd Ukraine Conference on Electrical and Computer Engineering (UKRCON), 2019, pp. 1179-1182. https://doi.org/10.1109/UKRCON.2019.8879941

\section{DATA ABOUT THE AUTHORS}

Victoria B. Malitskaya, Associate Professor of the Department of Accounting and Taxation

Plekhanov Russian University of Economics

36, Stremyanny per., Moscow, 117997, Russian Federation vmrussian@yandex.ru

Natalia N. Volkova, Associate Professor of Department of Accounting and Audit

Voronezh State Agrarian University named after Emperor Peter the Great

1, Michurin Str., Voronezh, 394087, Russian Federation natavolk73@yandex.ru

Anastasia A. Aksenova, Associate Professor of the Department of Accounting and Taxation

Plekhanov Russian University of Economics

36, Stremyanny per., Moscow, 117997, Russian Federation aaksenova.reu@gmail.com 
Irina E. Konovalenko, Senior Lecturer of the Department of Accounting and Taxation Plekhanov Russian University of Economics

36, Stremyanny per., Moscow, 117997, Russian Federation kie-irina@mail.ru

Dmitry N. Osyanin, Associate Professor of the Department of Accounting and Taxation Plekhanov Russian University of Economics 36, Stremyanny per., Moscow, 117997, Russian Federation dmitrii-osyanin@mail.ru

\section{ДАННЫЕ ОБ АВТОРАХ}

Малицкая Виктория Борисовна, профессор кафедры бухгалтерского учета и налогообложения Российский экономический университет имени Г.В. Плеханова пер. Стремянный, 36, г. Москва, 117997, Российская Федерация vmrussian@yandex.ru

Волкова Наталья Николаевна, доцент кафедры бухгалтерского учета и аудита Воронежский государственный аграрный университет имени имnератора Петра I

ул. Мичурина, 1, г. Воронеж, 394087, Российская Федерация natavolk73@yandex.ru

Аксенова Анастасия Андреевна, доцент кафедры бухгалтерского учета и налогообложения

Российский экономический университет имени Г.В. Плеханова пер. Стремянный, 36, г. Москва, 117997, Российская Федераџия aaksenova.reu@gmail.com

Коноваленко Ирина Евгеньевна, старший преподаватель кафедры бухгалтерского учета и налогообложения Российский экономический университет имени Г.В. Плеханова пер. Стремянный, 36, г. Москва, 117997, Российская Федерачия kie-irina@mail.ru

Осянин Дмитрий Николаевич, доцент кафедры бухгалтерского учета и налогообложения Российский экономический университет имени Г.В. Плеханова пер. Стремянный, 36, г. Москва, 117997, Российская Федерачия dmitrii-osyanin@mail.ru 